\title{
IbM Pengerajin Pandan Berduri Di Desa Tumbu Karangasem Bali
}

\section{Oleh}

Dewa Nyoman Sudana, dkk

\begin{abstract}
ABSTRAK
Desa Tumbu kabupaten Karangasem, ada pengerajin padan berduri, pandan berduri baru hanya digunakan sebagai tikar dan sebagian kecil untuk barang kerajinan yang menunjang tradisi adat dan agama Hindu di Bali. Kondisi ini tidak akan meningkatkan pendapat pengerajin padan berduri secara keseluruhan, karena demand market kecil. Hal ini terlihat dari kondisi masyarakat Desa Tumbu yang masih banyak di bawah garis kemiskinan. Dan masih sedikit yang mampu menyekolahkan anaknya ke perguruan Tinggi. Padahal desa tumbu terletak dekat dengan obyek wisata taman Soka Ujung Karangasem. Inspirasi dari kegiatan ini adalah potensi kerajinan dan daya dukung desa Tumbu yang belum termanfaatkan dengan baik, hal ini terlihat dari pengerajin, padan berduri kembang kempis dalam memasarkan produknya, karena desainnya monoton, maka ekspansi dan perluasan pasar enggan dikembangkan, sehingga penduduk Desa Tumbu tidak maksimal bergantung pada usaha kerajinan pandan berduri tersebut. Oleh karena itu, perlu dilakukan terobosan yang dapat membantu yakni pengembangan desain produk dan juga bantuan dalam hal penyiapan teknologi pengolahan.

Metode yang digunakan adalah pendampingan dengan membuat salah satu anggota kelompok pengerajin pandan berduri, setelah pendampingan dilakukan ekspose terhadap kelompok pengerajin lainnya. Karya utamanya adalah aneka desain, seperti berbagai jenis tas dengan motif yang beraneka ragam, termasuk tas untuk patung Ganesha. Hasilnya dipasarkan sebagai tempat patung Ganesha saat wisuda, kemudian alat /tikar solat unik

Ulasan karya utama adalah, produks desain antara lain tikar solat yang banyak diminati oleh para tamu domestik, kemudian tas untuk tempat cindera mata patung ganesha saat wisuda, Tas untuk laptop dan map untuk wisuda dan seminar. Desain produk ini sangat luas pemasarannya. Para pengerajin tampak antusias untuk melakukan diversifikasi usaha ini.

Kegiatan ini berdampak pada kepedulian pengerajin untuk bekerja tambahan, serta para kios-kios yang ada di dekat Taman Soka Ujung Karangasem telah mulai memasarkan produk-produk hasil P2M ini. Dengan demikian berdampak pada akses pasar dan pendapatan pengerajin pandan berduri di Desa Tumbu Karangasem.
\end{abstract}

Kata Kunci : Pandan berduri, Desa tumbu, Kerajinan

\begin{abstract}
Tumbu village of Karangasem district, there are thorny frontier craftsmen, new barbed pandanus mats and only used as a small part for goods that support the craft traditions and Hinduism in Bali. This condition will not improve prickly frontier craftsmen opinion as a whole, because the small market demand. This is evident from the condition of society which is still widely Tumbu village below the poverty line. And little is able to send their children to college Higher. Though Tumbu village situated close to the park attractions Soka Edge Karangasem. The inspiration of this activity is
\end{abstract}


the potential carrying capacity of rural crafts and Tumbu untapped well, it is seen from the craftsmen, frontier barbed flared flowers in marketing their products, because its design is monotonous, then the expansion and market expansion are reluctant to be developed, so that the villagers of Tumbu no maximum rely on such thorny pandanus handicraft business. Therefore, there should be a breakthrough that could help the development of product design and also help in the preparation of processing technology. The method used is mentoring by making one of the group members thorny pandanus craftsmen, having done an expose on the group mentoring other craftsmen. Its primary is a variety of designs, such as various kinds of bags with various motives, including bags for the statue of Ganesha. The result is marketed as a statue of Ganesha at graduation, then tools / unique prayer mat. The main work is reviewed, among other design produks prayer mats are much in demand by domestic guests, then bag for extra souvenirs Ganesha statue at graduation, bags for laptops and folders to graduation and seminars. The design is very broad product marketing. The craftsmen seem keen to diversify this business. These activities have an impact on the craftsmen to work an additional concern, as well as the stalls are near Taman Ujung Soka Karangasem has begun to market the products of this P2M. Thus the impact on market access and revenue thorny pandanus craftsmen in the village of Tumbu Karangasem.

Keywords: barbed Pandanus, Tumbu Village, Crafts

\section{A. PENDAHULUAN}

Desa Tumbu Kabupaten Karangasem, pandan berduri baru hanya digunakan sebagai tikar dan sebagian kecil untuk barang kerajinan yang menunjang tradisi adat dan agama Hindu di Bali. Kondisi ini tidak akan meningkatkan pendapat pengerajin padan berduri secara keseluruhan, karena demand marketnya kecil Hal ini terlihat dari kondisi masyarakat Desa Tumbu yang masih banyak di bawah garis kemiskinan. Dan masih sedikit yang mampu menyekolahkan anaknya ke perguruan Tinggi, informasi ini di dapat saat tim penyusun proposal, ikut serta membimbing mahasiswa ke Desa Tumbu.

Dari penuturan kepala Desa Tumbu, pengerajin, padan berduri kembang kempis dalam memasarkan produknya, karena desainnya monoton, maka ekspansi dan perluasan pasar enggan dikembangkan, sehingga penduduk Desa Tumbu tidak maksimal tergantung pada usaha kerajinan pandan berduri tersebut. Sebenarnya, dari kaca mata geografis, peluang pasar untuk aneka kerajinan berbahan dasar pandan sangat besar di Bali dan khususnya di Kabupaten Karangasem, sebab kabupaten Karangasem memiliki berbagai obyek wisata berkelas dunia, seperti Candidasa, Tulamben, Tirta Gangga dan Ujung( Taman Ujung). Kunjungan wisata ketempat itu luar biasa namun cindera mata yang dijajakan di obyek wisata tersebut, bukanlah hasil karya penduduk setempat melainkan di datangkan dari tempat lain. Akibatnya imbas 
pariwisata tidak terasa bagi mereka. Tentu, bila kondisi ini tidak tertangani dengan bijak, maka dunia pariwisata akan menimbulkan kecemburuan, dan akan menimbulkan dampak yang serius bila penduduk lokal, peran mereka termarginalkan. Apa bila kondisi ini terus terjadi maka pariwisata Bali dan khusus Kabupaten karangasem bisa terancam.

Sebenarnya, dari kaca mata geografis, peluang pasar untuk aneka kerajinan berbahan dasar pandan sangat besar di Bali dan khususnya di Kabupaten Karangasem, sebab kabupaten Karangasem memiliki berbagai obyek wisata berkelas dunia, seperti Candidasa, Tulamben, Tirta Gangga dan Ujung( Taman Ujung). Kunjungan wisata ketempat itu luar biasa namun cindera mata yang dijajakan di obyek wisata tersebut, bukanlah hasil karya penduduk setempat melainkan di datangkan dari tempat lain. Akibatnya imbas pariwisata tidak terasa bagi mereka. Tentu, bila kondisi ini tidak tertangani dengan bijak, maka dunia pariwisata akan menimbulkan kecemburuan, dan akan menimbulkan dampak yang serius bila penduduk lokal, peran mereka termarginalkan. Apa bila kondisi ini terus terjadi maka pariwisata Bali dan khusus Kabupaten karangasem bisa terancam.

Dalam dimensi bisnis global yang mendahulukan, clean industry, maka industri berbahan baku pandan berduri akan selalu tetap eksis, karena industri tersebut bertumpu pada industri yang ramah lingkungan Pandan berduri merupakan tanaman pantai yang dahulu tindak banyak dimanfaatkan. Namun sekarang ini, banyak perajin yang mulai memanfaatkan pandan untuk diolah menjadi berbagai aneka kerajinan. Pandan termasuk serat alam yang dapat dimanfaatkan untuk berbagai macam kerajinan. Lebih-lebih di Bali, dan khususnya di Desa Tumbu kabupaten Karangasem, pandan berduri baru hanya digunakan sebagai tikar dan sebagian kecil untuk barang kerajinan yang menunjang tradisi adat dan agama Hindu di Bali. Kondisi ini tidak akan meningkatkan pendapat pengerajin padan berduri secara keseluruhan, karena demand market-nya kecil Hal ini terlihat dari kondisi masyarakat Desa Tumbu yang masih banyak di bawah garis kemiskinan. Dan masih sedikit yang mampu menyekolahkan anaknya ke perguruan Tinggi, informasi ini di dapat saat tim penyusun proposal, ikut serta membimbing mahasiswa ke Desa Tumbu.

Dari penuturan kepala Desa Tumbu, pengerajin, padan berduri kembang kempis dalam memasarkan produknya, karena desainnya monoton, maka ekspansi dan perluasan pasar enggan dikembangkan, sehingga penduduk Desa Tumbu tidak maksimal tergantung pada usaha kerajinan pandan berduri tersebut. Sebenarnya, dari 
kaca mata geografis, peluang pasar untuk aneka kerajinan berbahan dasar pandan sangat besar di Bali dan khususnya di Kabupaten Karangasem, sebab kabupaten Karangasem memiliki berbagai obyek wisata berkelas dunia, seperti Candidasa, Tulamben, Tirta Gangga dan Ujung( Taman Ujung). Kunjungan wisata ketempat itu luar biasa namun cindera mata yang dijajakan di obyek wisata tersebut, bukanlah hasil karya penduduk setempat melainkan di datangkan dari tempat lain. Akibatnya imbas pariwisata tidak terasa bagi mereka. Tentu, bila kondisi ini tidak tertangani dengan bijak, maka dunia pariwisata akan menimbulkan kecemburuan, dan akan menimbulkan dampak yang serius bila penduduk lokal, peran mereka termarginalkan. Apa bila kondisi ini terus terjadi maka pariwisata Bali dan khusus Kabupaten karangasem bisa terancam.

Berangkat dari konsep pemikiran itu, salah satu solusi adalah mengadvokasi dan membina para pengerajin dan pengusaha kerajinan dari pandan berduri di Desa Tumbu Karangasem yang saat ini benar-benar lemah. Pasalnya produk-produk mereka banyak diminati turis mancanegara, namun tidak mampu berproduksi banyak dan beragam dalam desain, karena mereka adalah pekerja sambilan. Walaupun pandan mudah didapat di desa Tumbu dan relatif bahan baku ini didapat tanpa mengeluarkan ongkos untuk bahan baku, sehingga relatif murah, namun kendala yang dihadapi adalah kreativitas dalam membuat kerajinan belum banyak berubah mengikuti trend pasar dunia.Akibatnya, usaha kerajinan di Desa Tumbu belum mampu menghidupi keluarga secara penuh. Kini, hanya $20 \mathrm{KK}$ yang benar-benar masih menjadi pengerajin di Desa Tumbu, dan yang terlibat hanya golongan manula, sedangkan usaha produktif lain mengambil pekerjaan lain ke kota (baik ke Denpasar maupun ke Amlapura, dan kabupaten lain di Bali). Padahal, luas areal yang ditumbuhi pandan berduri relatif sangat luas sekitar 10 hektar lebih, sehingga pemasok bahan baku masih mampu enyerap lebih luas lapangan pekerjaan.

Kebutuhan modal untuk membuka usaha kerajinan pandan tidak besar. Usaha kerajinan pandan dapat dimulai dengan modal kecil. Oleh karena itu, ini merupakan peluang bagi para calon usahawan untuk segera bergerak memulai usaha kerajinan pandan

Desa Tumbu dengan pengerajin pandan berdurinya, merupakan desa yang kaya akan pandan berduri, dan belum maksimal dimanfaatkan. Kondisi itu tersebut akan mendorong pertumbuhan industri kerajinan berbahan bahan baku pandan berduri. Bila mendapat sentuhan teknologi bahan, desain dan teknologi pemasran, 
serta suntikan modal bagi pengerajin. Oleh karena itu, Ibm untuk pengerajin padan berduri di desa Tumbu Karangasem penting untuk dilaksanakan. Harapannya adalah perguruan tinggi sebagai cikal bakal untuk menumbuhkan suatu budaya baru bagi pengerajin, yang pada akhirnya dapat meningkatkan status ekonomi pengerajin tersebut.

Titik orientasi kegiatan pengabdian pada masyarakat (P2M) ini adalah kelompok pengerajin Pandan berduri di Desa Tumbu, Kecamatan Karangasem, Kabupaten Karangasem Bali, yang masih menghadapi kendala utama berupa kurangnya desain kerajinan pandan berduri yang sesuai dengan trend desain yang dimintai pasar, khususnya pasar pariwisata dunia. Yang lain adalah laju produksi yang lambat karena penguasaan teknologi pengolahan dan pemasaran. Berangkat dari permasahalan tersebut maka sumber inspirasi dalam kegiatan P2M ini adalah:

1. Mengatasi keterbatasan desain dari pengerajin pandan berduri di Desa Tumbu Karangasem, yang selama ini hanya bertumpu pada produk-produk tradisional, artinya kebutuhan masyarakat tradisional yang baru bisa dipenuhi, seperti tikar, upacara adat tradisional Bali. dan, masih sedikit untuk memproduksi desain untuk kebutuhan pariwisata, sehingga diharapkan dengan aneka jenis desain diberikan kepada para pengerajin pandan berduri maka hasil produksi laku terjual, sehingga pengerajin akan mendapat nilai tambah.

2. Peningkatan laju produksi dengan managemen dan teknologi baru dalam hal pengolahan, pemetikan, pemotongan serta desain dengan menggunakan teknologi tepat guna untuk pengerajin pandan.

3. Peningkatan penerapan teknologi pelapisan agar bahan pandan berduri itu menjadi tahan terhadap air.

4. Peningkatan kemampuan pemasaran. Produk-produk bahan baku pandan berduri belum memiliki pasar yang luas. Artinya produk itu dipasarkan sebatas di pasar tradisioal. Jaringan pasar belum terjalin dengan baik.

5. Kekurangan modal usaha.Untuk melanjutkan usaha ini perlu modal yang banyak dan tenaga pengerajin yang lebih muda. Kekurangan modal ini menyebabkan kurangnya inovasi produksi. 


\section{B. MATERI DAN METODE}

Materi yang digunakan adalah pandan, mesin jahit, dan pisau, benang. Metode penerapan IPTEKS dalam pengabdian ini adalah (1) Menerapkan pelatihan, yakni memberikan pelatihan tentang Penelusuran desain sebagai berikut :

Dengan langkah-langkah sebagai berikut :

(2) metode yang dilakukan untuk memproduksi wine adalah dengan Pelatihan membuat wine, yaitu dilakukan dengan langkah-langkah sebagai berikut :

Metode yang digunakan untuk membuat pupuk dan biopestisida alami sebagai berikut dan koperasi melalui pembuatan panitia kecil dan selesai dalam bentuk draf usulan ke Dinas koperasi kabupaten Buleleng.

Untuk efektivitas kegiatan dilakukan dengan Metode observasi dan wawancara Penulis mengadakan pengamatan di Desa Dencarik Kecamatan Banjar. Observasi dilakukan setelah memperoleh izin dari pihak-pihak terkait. Selain observasi penulis juga melakukan wawancara dengan pihak terkait guna menunjang pengumpulan data awal sebelum membuat usulan kegiatan program dan pelaksanaan program. Untuk kedepannya pun jika program telah terlaksana maka akan diadakan observasi wawancara lanjutan terkait dalam memperoleh informasi tindak lanjut kegiatan yang dilakukan masyarakat dari hasil penelitian. Observasi juga dilakukan setelah pelatihan diadakan, untuk mengetahui manfaat hasil pelatihan. Pada observasi ini dicari data mengenai tingkat keberhasilan pembuatan kerajinan tangan dengan bahan dasar pandan berduri.

Untuk menjawab permasalahan di atas perlu dilakukan usaha-usaha yang terpadu sebagai solusi untuk meningkatkan keterampilan pengerajin pandan berduri melalui pengenalan desain, teknologi proses untuk tahan air, memberikan wawasan pada generasi muda untuk mencintai kerajinan dari daun pandan berduri, pemasaran dan penambahan modal. Masalah itu hendak diberikan solusi dalam Ibm yang diusulkan ini. Adapun solusi yang dimaksud adalah sebagai berikut :

Tabel 1 Permasalahan Pengerajin Pandan berduri dan solusi yang ditawarkan

\begin{tabular}{|l|l|l|}
\hline Permasalahan & Akar masalah & $\begin{array}{l}\text { Pendekatan } \\
\text { pemecahan masalah } \\
\text { (solusi) }\end{array}$ \\
\hline $\begin{array}{l}\text { Keterbatasan desain, } \\
\begin{array}{l}\text { Pengerajin pandan } \\
\text { berduri di Desa }\end{array}\end{array}$ & $\begin{array}{l}\text { 1. Pengerajin tidak } \\
\text { berinovasi sesuai } \\
\text { dengan trend }\end{array}$ & $\begin{array}{l}\text { Memberikan pelatihan } \\
\text { terstruktur tentang } \\
\text { berbagai desain yang }\end{array}$ \\
\hline
\end{tabular}




\begin{tabular}{|l|l|l|}
\hline Tumbu Karangasem & $\begin{array}{l}\text { 2. Pengetahuan tentang } \\
\text { desain yang trend } \\
\text { belum dikathaui . }\end{array}$ & trend \\
\hline $\begin{array}{l}\text { Kemampuan } \\
\text { produksi rendah }\end{array}$ & $\begin{array}{l}\text { Penerajin tidak memiliki } \\
\text { pengetahuan } \\
\text { memamfaatkan teknologi } \\
\text { tepat guna. }\end{array}$ & $\begin{array}{l}\text { Pelatihan menggunakan } \\
\text { teknologi tepat guna. }\end{array}$ \\
\hline $\begin{array}{l}\text { Sifat bahan yang } \\
\text { mudah rusak bila } \\
\text { kena air, }\end{array}$ & $\begin{array}{l}\text { Pengerajin tidak memiliki } \\
\text { pengetahuan tentang sifat- } \\
\text { sifat bahan yang dapat } \\
\text { mengatasi kerusakan } \\
\text { karena air }\end{array}$ & $\begin{array}{l}\text { Pelatihan menggunakan } \\
\text { berbagai pelapisan } \\
\text { dengan menggunakan } \\
\text { bahan yang anti air. }\end{array}$ \\
\hline $\begin{array}{l}\text { Kekurang } \\
\text { pengetahuan } \\
\text { pemasaran. }\end{array}$ & $\begin{array}{l}\text { Pengerajin kurang } \\
\text { menguasai cara-cara } \\
\text { pemasaran produk } \\
\text { kerajinan }\end{array}$ & $\begin{array}{l}\text { Pelatihan teknik } \\
\text { pemasaran kerajinan } \\
\text { berbasiskan web }\end{array}$ \\
\hline $\begin{array}{l}\text { Kekurangan modal } \\
\text { usaha. }\end{array}$ & $\begin{array}{l}\text { Pengerajin kurang } \\
\text { memanfaatkan koperasi } \\
\text { untuk mengembangkan } \\
\text { usaha }\end{array}$ & $\begin{array}{l}\text { Penyuluhan tentang } \\
\text { petingnya koperasi }\end{array}$ \\
\hline $\begin{array}{l}\text { Menjadi pusat/sentra } \\
\text { kerajinan } \\
\text { yang sangat memikat. }\end{array}$ & $\begin{array}{l}\text { Pengerajin belum memiliki } \\
\text { pengetahuan tentang } \\
\text { manfaat sentra kerajinan } \\
\text { daun padan berduri }\end{array}$ & $\begin{array}{l}\text { Pendampingan proposal } \\
\text { untuk dilanjutkan ke } \\
\text { Pemkab Karangasem }\end{array}$ \\
\hline
\end{tabular}

\section{Metode Observasi dan Wawancara}

Penulis mengadakan pengamatan di Desa Tumbu. Observasi dilakukan setelah memperoleh izin dari pihak-pihak terkait. Selain observasi penulis juga melakukan wawancara dengan pihak terkait guna menunjang pengumpulan data awal sebelum membuat usulan kegiatan program dan pelaksanaan program. Untuk kedepannya pun jika program telah terlaksana maka akan diadakan observasi wawancara lanjutan terkait dalam memperoleh informasi tindak lanjut kegiatan yang dilakukan masyarakat dari hasil penelitian. Observasi juga dilakukan setelah pelatihan diadakan, untuk mengetahui manfaat hasil pelatihan. Pada observasi ini dicari data mengenai tingkat keberhasilan pembuatan kerajinan tangan dengan bahan dasar pandan berduri.

\section{Metode Penyuluhan dan Pelatihan}


Metode yang digunakan untuk mencapai tujuan yang telah dirumuskan di depan adalah metode diskusi dan praktek (learning by doing). Gabungan kedua metode tersebut diharapkan mampu meningkatkan pemahaman dan keterampilan khalayak berkaitan dengan teknik pembuatan kerajinan tangan. Keterkaitan antara tujuan dan metode yang dipakai untuk mencapai tujuan dapat dilihat pada Tabel 2.

Tabel 2. Keterkaitan Masalah dan Metode Kegiatan

\begin{tabular}{|l|l|l|l|}
\hline No & \multicolumn{1}{|c|}{ Tujuan } & Metode & \multicolumn{1}{|c|}{ Bentuk Kegiatan } \\
\hline \hline 1 & $\begin{array}{l}\text { Mengenalkan dan } \\
\text { memberikan pelatihan tentang } \\
\text { teknik pemanfaatan pandan } \\
\text { berduri sebagai kerajinan } \\
\text { tangan }\end{array}$ & $\begin{array}{l}\text { Ceramah } \\
\text { dan } \\
\text { Praktek }\end{array}$ & $\bullet \begin{array}{l}\text { Ceramah tentang tanaman pandan } \\
\text { berduri, dan pemanfaatan pandan } \\
\text { berduri sebagai kerajinan tangan. }\end{array}$ \\
\hline 2 & $\begin{array}{l}\text { Untuk mengetahui } \\
\text { tanggapan/respon ataupun } \\
\text { manfaat yang dirasakan }\end{array}$ & Observasi & • \\
$\begin{array}{l}\text { Penger Desa Tumbu } \\
\text { Kecamatan } \\
\text { Karangasemterhadap } \\
\text { pengenalan dan pelatihan } \\
\text { teknik pemanfaatan pandan } \\
\text { berduri sebagai kerajinan } \\
\text { tangan. }\end{array}$ & $\begin{array}{l}\text { yang mengikuti pelatihan } \\
\text { pemanfaatan pandan berduri } \\
\text { sebagai kerajinan tangan }\end{array}$ \\
\hline
\end{tabular}

\section{Metode penyuluhan dan pelatihan}

Dalam kegiatan P2M ini, metode yang digunakan untuk mencapai tujuan yang telah dirumuskan di depan adalah metode diskusi dan praktek (learning by doing). Gabungan kedua metode tersebut diharapkan mampu meningkatkan pemahaman dan keterampilan khalayak berkaitan dengan teknik pembuatan beberapa desains baru, yang memiliki nilai jual tinggi.

\section{HASIL DAN PEMBAHASAN}

Karya utama kegiatan ini adalah

1. Model desain kerajinan pandan berduri

2. Metode pemasaran kerajinan 


\section{C2. PEMBAHASAN}

1. Disain. Bukan perkara susah cari pekerjaan lainnya, tapi karena faktor peduli terhadap lingkungan akibat banyaknya tumbuh tanaman pandan berduri di desa tersebut sehingga sebagian besar ibu rumah tangga yang juga berprofesi sebagai petani memanfaatkan waktu luangnya untuk membuat tikar pandan. Keahlian membuat tikar pandan ini telah ada sejak puluhan tahun silam dan dimiliki secara turun-temurun oleh warga di sana. Setidaknya, setiap hari para ibu rumah tangga melalui pekerjaan sambilan ini dapat menambah pendapatan bagi keluarga mereka Rp 20.000,- sampai dengan Rp 30.000,--

2. Tikar untuk solat, proses produksinya cukup sederhana. Daun pandan berduri yang cukup dewasa dengan lebar sekitar 5-7 cm di potong. Kemudian dengan sisir khusus, duri-duri pada daun tersebut disisir sehingga rontok. Daun yang bebas duri kemudian dijemur 3-5 hari sesuai kondisi matahari hingga cukup mengering. Kemudian daun tersebut di press agar menjadi tipis dan lemas dan dilanjutkan dengan dijemur beberapa jam. Daun pun siap dianyam.

3. Untuk tempat patung. Proses penganyaman pada dasarnya masih cukup sederhana, tapi untuk dapat menghasilkan 1 lembar tikar ukuran 120 x 200 cm dalam waktu sehari tentunya memerlukan kemampuan cekatan yang tinggi. Setelah berhasil dianyam, lembaran-lembaran tersebut di tumpuk 23 lapisan untuk kemudian dipotong sesuai bentuk ukuran tikar dan dijahit pada sisi-sisinya. Rata-rata para ibu rumah tangga di sana dapat membuat 1-2 tikar dalam sehari tergantung pada ukuran tikar yang dibuat. Tikar anyaman tersebut dijual kepada pengepul dengan harga Rp 20.000,sampai dengan Rp 60.000,- tergantung pada ukuran dan ketebalan/jumlah lapisan tikar.

\section{KESIMPULAN}

Dari uraian di atas dapat disimpulkan bahwa kegiatan IbM untuk pengerajin pandan berduri di Desa Tumbu Karangasem telah dapat berlangsung dengan baik. Hasil karya utamanya adalah adanya inovasi desain dan jangkauan pasar yang lebih luas. 


\section{E. DAMPAK DAN MANFAAT KEGIATAN}

Hasil kegiatan pengabdian ini mendapatkan apresiasi baik dari pemerintah khususnya dinas perindustrian dan perdagangan. Untuk bisa bekerja sama untuk membantu menyiapkan berbagai kegiatan untuk ikut menyelaraskan dengan kegiatan P2M Undiksha ini. hal ini akan dikembangkan untuk Kerajinan tikar pandan, demikian budaya terampil tersebut dikenal oleh kalangan masyarakat di desa itu. Desa yang memiliki 7 dusun ini dengan sekitar 2.400 jiwa penduduknya banyak yang berprofesi sebagai pembuat tikar pandan, setidak nya terdapat sekitar 400 orang pengrajin yang mayoritas mereka adalah ibu rumah tangga.

\section{F. UCAPAN TERIMA KASIH}

Ucapan terima kasih dan penghargaan yang tinggi diberikan kepada Camat Karangasem, Perbekel Desa Tumbu. Kelompok pengerajin pandan berduri Desa Tumbu Karangasem. Ucapan terima kasih yang setinggi-tinggi kami juga dihaturkan kepada DP2M DIKTI atas dana Hibah Program Pengabdian IbM tahun 2011, Rektor Undiksha atas izin dan dorongannya selama ini, Ketua LPM Undiksha, rekan-rekan dosen jurusan pendidikan Guru Sekolah Dasar, FIP Undiksha yang selalu mendorong penulis untuk melakukan kegiatan pengabdian ini.

\section{G. DAFTAR PUSTAKA}

1) Anonim. 1990. Undang-undang No. 9 Tahun 1999 Tentang Kepariwisataan. Jakarta.

2) Anonim. 1995. Laporan Akhir Studi Pengembangan Wisata Minat Khusus (Tak dipublikasikan) Yogyakarta: Dinas Pariwisata DI Yogyakarta dan Pusat

3) Penelitian dan Pengembangan Pariwisata (PUSPAR) UGM: Yogyakarta.

4) Fandeli. C. 1995. Dasar-dasar Kepariwisataan Alam. Yogyakarta: Liberty.

5) Fandeli, C. 1999. Ekowisata Dalam Paragdigma Baru Pariwisata (Tak dipublikasikan). Makalah semiloka "Sustainable Tourism Depelopment"di Universitas Jendral Sudirman. Purwokerto, tanggal 22-25 Februari 1999.Purwokerto.

6) Echols, J.M. 1992. Kamus Inggris Indonesia. Jakarta: PT Gramedia.

7) Hardjasoemantri, K. 1991. Hukum Perlindungan Lingkungan Konservasi Sumberdaya Alam Hayati dan Ekosistemnya. Yogyakarta: Gadjah Mada. University Press.

8) Hasansulama, M.I. dkk. 1983. Sosiologi Pedesaan. Jakarta: Departemen Pendidikan dan Kebudayaan. 
9) Kuncoro, E.H. 1995. Partisipasi Masyarakat Sekitar Hutan dalam Pelaksanaan Management Regime. Tesis S-2 (Tak dipublikasikan). Program Pasca Sarjana UGM. Yogyakarta.

10) Mac Kinnon dkk. 1986. Pengelolaan Kawasan yang Dilindungi di Daerah Tropika. Terjemahan dari Managing Protected Areas in Tropica. Swiss: IUCN, Yogyakarta: Gadjah Mada University Press.

11) Nurtjahjo, Agus T.P. 1994. Partisipasi Masyarakat Sekitar Hutan Lindung dalam Kegiatan Reboisasi. Tesis S-2 (tak dipublikasikan) Program Pasca Sarjana UGM Yogyakarta.

12) Parikesit, D dan Muliawan, H. 1997. Prospek dan Strategi Pengembangan Wisata Minat Khusus di Indonesia (Tak dipublikasikan). Makalah Seminar Nasional Gegama. Fakultas Geografi UGM tanggal 8 September 1997 di Yogyakarta.

13) Qomar, N. 1997. Studi Potensi Biogeofisik untuk Pengembangan Wisata Alam di Kawasan HPH Dwima Group Kalimantan Tengah (Tak dipublikasikan).Skripsi S-1 Fakultas Kehutanan UGM Yogyakarta. 